\title{
The Role of the Hungarian Defence Forces Skills in the Protection against Water Damages - The Extraordinary Flood on the Danube River 2013
}

\author{
A honvédelmi képességek szerepe a hazai \\ vízkárelhárításban - a 2013. évi rendkívüli dunai árvíz \\ tükrében
}

The role of the Hungarian Defence Forces in the National water damage prevention is unquestionable due to the available human resources and technical preparedness. It can be stated that the Hungarian Defence Forces capabilities complement the capacity of the Hungarian Flood protection. The collaboration has always been professional and well-functioning, for example there were several flood defence and protection against ice events activities in the Hungarian Rivers that exceed the highest measured water level. In this article I present the main elements of the involvement of the Hungarian Defence Forces' activities in the extraordinary Danube Flood in 2013.

Keywords: defence forces, skills, flood protection, protection activity

A Magyar Honvédség szerepe a hazai vízkárelháritásban az igénybe vehetö humán eröforrás állománya és technikaifelkészültsége miatt megkérdőjelezhetetlen. Kijelenthetö, hogya honvédelmi képességek kiegészítik a vízügyi szolgálat képességeit. Az együttmüködés mindig szakszerüen és jól müködött, példa erre a hazai vízfolyásainkon levonuló több, az eddigi mért legnagyobb vízállást meghaladó árvízi védekezés és a folyóinkon történt jég elleni védekezés is. Jelen cikkemben a honvédelmi erök bevonásának föbb mozzanatait mutatom be a 2013. évi rendkivüli dunai árvíz elleni védekezésben.

Kulcsszavak: honvédelem, képesség, árvízvédelem, védekezés

National University of Public Service, KMDI, e-mail: kristofdobo@gmail.com, ORCID: 0000-0002-1703-8211

National University of Public Service, e-mail: toth.rudolf@chello.hu, ORCID: 0000-0002-6013-7899 


\section{Introduction, Historical Overview}

It can be stated that the role of the Hungarian Defence Forces in the National water damage prevention is unquestionable. The application of the military in the flood protection activities has a long history.

The March 1838 ice flood damaged 2,281 houses in Pest, 204 houses in Buda and 397 in Óbuda. In the three cities there were 1,363 houses damaged and thousands of destroyed houses along the Danube River. The possibility of ice floods was already visible in mid-December, but the protection activity against the ice flood was completely ineffective. This was the first time that the ice was trying to break down by blasting. At the river section under the Gellért Hill, the ice stopped at the beginning of March. It is well-known that cannon shots signalled danger, but the fact that they tried to break the ice with gunpowder filled into wells is only mentioned in the literature (Mór Jókai: Kárpáti Zoltán). The ignition of gunpowder would have launched a wick pulled into a thinner tube, but failed after half an hour. ${ }^{3}$

The next decades had similar tasks for the military. The military expertise was often needed in flood rescue and in blasting ice jams, but the first serious activity was in 1879 at the scene of the flood event in Szeged. ${ }^{4}$

The wide range of tasks performed covered the following tasks: sheeting, dyke strengthening, filling sand bags, building temporary flood protection dikes, protection against sand boils, excavation, transporting, maintenance of roads, blasting activities, lighting of night workplaces, saving livestock and crops, providing temporary placement for the saved/resettled population, sheltering and observation/detection from aircrafts. ${ }^{3}$

The past decades of post-defensive evaluations agree that the application of the Hungarian Defence Forces, its special equipment park and its preparedness, organisation and ability to work are essential in defences against extreme flooding. Nowadays, the legal framework for involving defence capabilities in water damage prevention is set out in Act CXIII of 2011. The law regulates the defence and the Hungarian Defence Forces, as well as the measures that can be introduced in the special legal order. Article 36 (2) a. of this special legal order contains the tasks of the Hungarian Defence Forces related to disaster management. It can be stated that the role of the Hungarian Defence Forces is organised and precisely defined in the Hungarian water damage control system. ${ }^{5}$

In the following, I will present the deployment experiences of the Hungarian Defence Forces in the last serious nationwide flood protection activities. Therefore, I consider it very important to present the flood situation, the major protection interventions and measures in order to be able to objectively summarise the experiences.

PADÁNYI 1994, 56.

TÓTH 2012.

Act CXIII of 2011 on National Defence and the Hungarian Defence Forces. 


\section{The Extraordinary Flood in the Danube River in 2013 and the Flood Protection Measures and Activities}

Before I present the hydrological and hydraulic characterisation of the extraordinary flood, the flood protection activities and capabilities of the Hungarian Defence Forces, I consider it very important to highlight the 7/2012 Regulation of the Ministry of the Interior, which contains the national management and operation rules of the Hungarian water damage prevention. In case of ordering an emergency situation, regarding the 7/2012 Regulation of the Ministry of the Interior, the national control of the flood defence is carried out by the Inter-Ministerial Coordinating Committee for Disaster Management together with the National Technical Committee. ${ }^{6}$

\section{Hydrological and hydraulic characterisation of extraordinary flood}

At the end of May, there was a low pressure and cold air waves have settled for several weeks over Central and Western Europe. This low pressure cyclone moved hardly and slowly. In low pressure areas, the cyclones causing rainy weather stay longer, in the higher pressure, the anticyclones cause dry weather. The cyclone which directly caused the Danube flood, was part of such a planetary wave that was not moving for weeks.

The June 2013 flood on the Danube River consisted of three major parts: the flood on the upper region of the Danube, the flood of the Inn and the floods of the Austrian river tributaries. This precipitation, which caused the flood waves - due to the time difference - corresponding to the distance of the tributaries, increased the Danube flood discharge with 1-1 days.

The flood wave exceeded the highest measured water level in every water gauge station, except Mohács, which means that new highest water levels were born along the Hungarian Danube river section. Table 1 contains the new highest water level measurements along the Hungarian Danube River section. The last column of this table shows the differences between the previous and recent (June 2013) measured highest water levels.

$6 \quad 7 / 2012$ (II. 10.) Regulation of the Ministry of the Interior. 
Table 1. The recent and newest highest water levels in the Hungarian Danube River section

\begin{tabular}{|c|c|c|c|c|c|}
\hline \multirow{2}{*}{ Water level gauge station } & \multicolumn{2}{|c|}{ The Highest Water Level (HWL) } & \multicolumn{2}{|c|}{2013} & \multirow{2}{*}{$\begin{array}{c}\text { Difference } \\
\qquad(\mathrm{cm})\end{array}$} \\
\hline & Year & $\mathrm{cm}$ & $\begin{array}{l}\text { Flood peak water } \\
\text { level }(\mathrm{cm})\end{array}$ & Date & \\
\hline Vámosszabadi & 2002 & 845 & 876 & 07.06.2013. 19:04 & 31 \\
\hline Nagybajcs & 2002 & 875 & 907 & 07.06.2013.21:05 & 32 \\
\hline Gönyü & 2002 & 832 & 857 & 08.06.2013. 06:16 & 25 \\
\hline Komárom & 2002 & 801 & 845 & 08.06.2013.17:23 & 44 \\
\hline Esztergom & 2002 & 771 & 813 & 09.06.2013.04:07 & 42 \\
\hline Nagymaros & 2006 & 714 & 751 & 09.06.2013. 13:16 & 37 \\
\hline Budapest & 2006 & 860 & 891 & $09.06 .2013 .20: 03$ & 31 \\
\hline Dunaújváros & 1956 & 742 & 755 & 11.06 .2013 .01 & 13 \\
\hline Dunaföldvár & 1956 & 703 & 721 & 11.06.2013. 04:11 & 18 \\
\hline Paks & 1956 & 872 & 891 & 11.06.2013. 07:16 & 19 \\
\hline Dombori & 1956 & 894 & 916 & $11.06 .2013 .18: 03$ & 22 \\
\hline Baja & 1956 & 976 & 989 & 12.06 .2013 .05 & 13 \\
\hline Mohács & 1956 & 984 & 964 & 13.06.2013. 03:12 & -20 \\
\hline
\end{tabular}

Source: Report of the National Technical Steering Tribunal for the 2013 Danube Flood Assessment, 2013.

\section{Introduction of Flood Protection Activities of the Hungarian Defence Forces}

I would like to introduce the water damages prevention activities of the Hungarian Defence Forces on the 2013 extraordinary Danube flood.

\section{Introduction of tasks and implemented protection measures}

On 31 May, the Chief of Defence Headquarters ordered for the leading bodies of the Defence Disaster Management System to clarify workgroups that could be involved in the flood protection tasks and ordered the implementation of a survey of additional forces and involved assets by the deadline of June 3, 2013.

After the processing of incoming reports, measures have been issued, requiring further clarification, in particular on the specific technical equipment that can be involved in flood protection activities requested by the water sector for providing assistance in water damage prevention (PTSZ-M medium floating transport vehicles, KD-84 light planer sets, seeder boats and boats). 
The State Secretary of the Ministry of Defence, after the first indication of the possible use of military forces, on 3 June 2013 ordered the activation of some of the leading elements of the Defence Disaster Management System, and extended the scope of the forces to the voluntary reserve stock; on the same day they were instructed in Regulation No. 45/2013.

On June 3, 2013, the Minister of Defence issued the ordering of flood protection forces in Regulation No. 47/2013, which allowed for the Hungarian Defence Forces to use more than 200 people at the same time for participating in the flood protection activities. On June 5 , 2013 at 2 p.m., the number of ordered and on-call staff reached 3,000, so the Defence Minister informed the President of the Defence and Law Enforcement Committee.

Then the Chief of Defence Headquarters clarified the Hungarian Defence Forces flood protection tasks by defining a frame number of 8,000 and a possibility of engaging the Defence Disaster Management System. The main tasks of the Hungarian Defence Forces were saving lives and properties, strengthening state and governmental flood protection dykes, that was previously agreed with the National Technical Committee.

Following the announcement by the Government of an emergency on 12 June 2013 at 12 noon and taking into account the forecast and needs of the National Technical Committee, the Chief of Defence Headquarters issued its operational concept for the implementation of the spring 2013 flood protection tasks.

This concept included the expected tasks of the Hungarian Defence Forces, operational areas, designated base warehouses and relevant organisations. The concept also included the tasks of supporting the operation, calling on volunteer operations and security reserves for flood protection tasks and the order of management and cooperation. The following implementations were also ordered: relocation of the military forces and special technical equipment from the eastern part of the country (4 helicopters Mi-8/17, 12 PTSZ-M tracked vehicles) to endangered sections area, to ensure the capabilities to be established at each military organisation, to repatriate the soldiers on leave and to suspend the training and later the training to be carried out.

For the safety and smooth flight of aircraft involved in the flood protection activities from 6 June 2013, the National Aviation Authority restricted the use of airspace to others.

The Hungarian Defence Forces application for disaster protection received a total of 82 requests: 58 requests coming from county defence committees, 15 requests from the National Technical Committee and the Inter-Ministerial Coordinating Committee for Disaster Management, 9 requests from the National Directorate General for Disaster Management, National Rescue Service and National Police Headquarters. The demands basically concerned the Hungarian Defence Forces transport vehicles and its special technical equipment.

At the same time, as the deployment of the forces got involved in the defence, the voluntary reserve was called and, as of June 5,2013 , a total of 1,404 people participated in the flood protection activities. 
During the flood defence period, the Hungarian Defence Forces took part in the following tasks:

1. Manual reinforcement work:

- filling sandbags

- building ribbed support

- dyke heightening

- dyke strengthening

- dyke heightening with temporary flood protection works

- building localisation lines

2. helicopter loading tasks

3. crawler transport vehicle transport tasks

4. diving tasks; control, monitoring and patrol

5. provision of placement and investment material for the displaced population

6. air reconnaissance, aerial photography, air patrolling (using unmanned aerial equipment - SUAV)

The Hungarian Defence Forces focused their efforts on the planning of the occupation of over 9,600 people in four divisions:

- No. 1 District: Györ-Moson-Sopron County

- No. 2 Division 2: Defence Section between Komárom-Dömös

- No. 3 Areas of defence between the southern boundary of Dömös and Budapest

- No. 4 Areas of Control between Kalocsa-Baja and Decs-Bata

During the execution of the task, the largest number of personnel was present on June 9, 2013; 7,011 people were employed in defence tasks and another 1,900 were available in the base warehouse.

The State Secretary of the Ministry of Defence terminated the partial activation of certain leadership elements of the Defence Disaster Management System on June 17, 2013, at 8.00 a.m., after which the forces of the Hungarian Defence Forces assigned to flood protection tasks returned to their peacekeeping districts.

\section{Providing human resources for flood control activities}

On the basis of the 06.00 hour reports of the Emergency Operational Tribunal, the number of the personnel of the Hungarian Defence Forces was taken into account daily, as shown in Figure 1. 


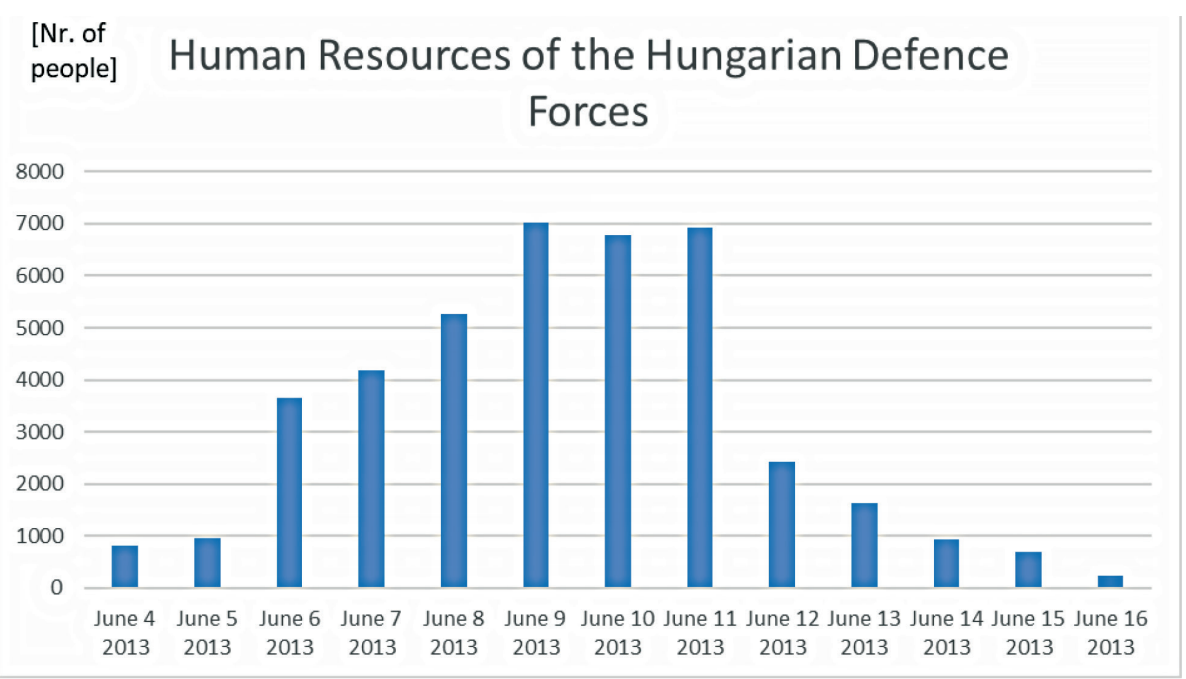

Figure 1. Involvement of the Human Resources of the Hungarian Defence Forces

Source: Report of the National Technical Steering Tribunal for the 2013 Danube Flood Assessment, 2013.

The logistical support of the staff assigned to the defence tasks was implemented on the basis of the internal professional regulations and measures, according to which the main forces of the logistic support are:

- During the preparation phase, to prepare the designated technical equipment, provide the personnel with protective equipment, organise the logistical reinforcement of the designated base repositories and plan the necessary transfers.

- During the implementation period, to focus on the logistical strengthening of base assets, the redeployment of the necessary assets and materials, and the provision of personnel.

The logistical support system is based on a system of base objects (with a living logistical system operating in peace) and in defence zones, appropriately focusing on the necessary logistics capabilities.

Organising its logistical support, the Hungarian Defence Forces paid special attention to the provision of the equipment of the voluntary reserve stock, the organisation of its provision and its transfer to the endangered area.

During the defence period, using the full logistical capability of the army, in addition to providing peace support for military organisations not involved in defence, 5 Camp Supply Groups were established and transferred to designate base barracks and base objects.

About 750 people have implemented logistical support for flood control tasks.

Based on previous flood control protection experiences, a logistical support system based on base repositories fully ensured the supply of personnel, the provision of equipment for Volunteer 
Reserve Soldiers, the re-allocation and use of technical equipment and tools for defence, which essentially contributed to the successful execution of tasks.

\section{Used resources of the Hungarian Defence Forces in the flood control activities}

The Hungarian Defence Forces $(\mathrm{MH})$ carried out 8,466 on-site applications on the entire section of the Danube, with the designation of 4 protection districts, and carried out in 28 locations air, land and underwater works related to dam reinforcement. The Hungarian Defence Forces supported the defence with the use of crawler, ground, water and airborne equipment, capabilities, transportation, control, surveillance, patrol, placement, aerial exploration and investment materials.

According to the technical reports of the Hungarian Defence Forces on the basis of the 06.00 hour reports of Disaster Management Operational Tribunal, they were included in Table 2.

Table 2. Applied technical equipment of the Hungarian Defence Forces

\begin{tabular}{|c|c|c|c|c|}
\hline \multirow[t]{2}{*}{ Date } & \multicolumn{4}{|c|}{$\begin{array}{l}\text { Applied technical equipment and application number during the entire flood protection } \\
\qquad \text { activities }\end{array}$} \\
\hline & PTSZ-M & M I 8/17 helicopter & Vehicles & Summary \\
\hline 4 June 2013 & 2 & & 80 & 82 \\
\hline 5 June 2013 & 8 & 4 & 121 & 133 \\
\hline 6 June 2013 & 8 & 4 & 292 & 304 \\
\hline 7 June 2013 & 12 & 4 & 410 & 426 \\
\hline 8 June 2013 & 12 & 4 & 450 & 466 \\
\hline 9 June 2013 & 12 & 4 & 841 & 857 \\
\hline 10 June 2013 & 12 & 4 & 530 & 546 \\
\hline 11 June 2013 & 8 & 4 & 721 & 733 \\
\hline 12 June 2013 & 8 & & 40 & 48 \\
\hline 13 June 2013 & 4 & & 40 & 44 \\
\hline 14 June 2013 & 4 & & 8 & 12 \\
\hline 15 June 2013 & 4 & & 8 & 12 \\
\hline 16 June 2013 & & & 13 & 13 \\
\hline 17 June 2013 & & & 13 & 13 \\
\hline
\end{tabular}

Source: Report of the National Technical Steering Tribunal for the 2013 Danube Flood Assessment, 2013.

The Hungarian Defence Forces involved in flood defence totalled 1,591,116 working hours. The technical equipment made about 493,000 kilometres during the flood protection. 
The helicopters of the Hungarian Defence Forces contributed to the successful completion of the tasks with 192 take-offs with 101 hours of flight time and 1,100 entries with diving teams in 737 hours. About 800 vehicles, 24 PTSZ-M tracked floating vehicles, 4 helicopters MI-8 / MI-17 participated in the flood control activities.

\section{Summary}

During the execution, the Hungarian Defence Forces effectively and efficiently fulfilled the demand for the use of all military forces.

The basis for the effectiveness of the army contribution was the exact, lawful and timely operation. As a result of the rapid change of the situation during the implementation, effective coordination was a key task for the leading bodies, which was ensured by the national defence referrals and vice-presidents working at the county and local defence committees, as well as the liaison system operated by the defence bodies and the National Technical Committee.

The effective and coordinated implementation of defence tasks was greatly facilitated by the decision made at the beginning of the defence, which assigned the order of the national professional management to the water management sector.

It can be stated that the Hungarian Defence Forces at the leadership and organisational level were fully prepared to cooperate in the tasks of flood defence and to cooperate with the partner organisations involved in the defence.

In my opinion, it is also advisable in the future to clearly define the management order of the defence, the powers and responsibilities of the task forces and working groups in the early stages of the flood control activities.

\section{References}

PADÁNYI József (1994): A Magyar Honvédség müszaki csapatainak lehetőségei és feladatai békeidőben a természeti- és civilizációs katasztrófák megelözésében és a következmények felszámolásában. Doctoral candidate thesis, Miklós Zrínyi National Defence University, Budapest.

То́тн Ferenc (2012): Jégrobbantás évszázada Magyarországon [A Century of Icebreaking in Hungary]. Water Supply, Sewerage, Budapest.

Report of the National Technical Steering Tribunal for the 2013 Danube Flood Assessment (2013).

\section{Legal references}

Act CXIII of 2011 on National Defence and the Hungarian Defence Forces, and on measures to be introduced in the special legal order.

7/2012 (II. 10.) Regulation of the Ministry of the Interior on the organisational and operational rules of the national management of water damage prevention. 
